\title{
Interaction Between the Neglected Tropical Disease Human Schistosomiasis and HCV Infection in Egypt: a Puzzling Relationship
}

\author{
Mahmoud M. Bahgat ${ }^{1,2}$ \\ ${ }^{1}$ Immunology and Infectious Diseases Group, Therapeutic Chemistry Department, the Centre of Excellence for Advanced \\ Sciences, the National Research Centre, Dokki, Cairo, Egypt; ${ }^{2}$ Research Group of Biomarkers for Infection and Immunity, \\ Institute of Experimental Infection Research, TWINCORE Centre for Experimental and Clinical Infection Research, Hannover, \\ Germany
}

\begin{abstract}
Egypt has the highest prevalence of chronic hepatitis $C$ virus (HCV) infection and seropositivity worldwide, and it has been proposed that this enhanced susceptibility to $\mathrm{HCV}$ is related to coinfection with schistosomiasis. Although currently, there are no studies regarding the actual prevalence of both human schistosomiasis and schistosomiasis/HCV coinfection evidences strongly support that eliminating human schistosomiasis from Egypt is necessary to reduce both HCV prevalence and liver pathology. The present review highlights the significant impact of the neglected tropical disease human schistosomiasis on both susceptibility of Egyptians to HCV coinfection, severity of the resulting liver pathology, and poor response to antiviral therapy. The immune evasion mechanisms exerted by the HCV-NS3/4A protease domain, and the possible impact of immune evasion mechanisms exerted by proteases of larval, worm and egg stages of the parasite Schistosoma on human susceptibility to HCV infection are discussed. In addition, schistosome immune evasion mechanisms may include immunosuppression that in turn prevents clearance of HCV viremia and leads to relapsing HCV infection and severe liver pathology. I propose the generation of a replicon system from the most prevailing genotype (HCV$4 a)$ in Egypt and establishing its replication on hepatoplastoma or immune cells in presence of bilharzial antigens. Finally, the use of a humanized small animal model that can acquire both HCV and S. mansoni infections will be important to further understand in real time the impact of coinfection on
\end{abstract}

Keywords: Egypt; Neglected tropical disease; Human schistosomiasis; HCV; Coinfection; Immune evasion mechanisms; HCV protease; Schistosome proteases.

Abbreviations: $\mathrm{HCC}$, hepatocellular carcinoma; $\mathrm{HCV}$, hepatitis $\mathrm{C}$ virus; $\mathrm{HCV}-4 \mathrm{a}$, HCV genotype 4a; INF- $\gamma$, interferon gamma; IPS-1, interferon-beta promoter stimulator 1; IRF-3, IFN regulatory factor 3; ISGs, IFN-stimulated genes; MAVS, mitochondrial anti-viral signaling protein; NS, nonstructural protein; RIG-I, retinoic-acid inducible gene I; TNF- $\alpha$, tumor necrosis factor alpha; TLR3, Tolllike receptor 3; VISA, virus-induced signaling adaptor.

Received: 08 December 2013; Revised: 21 February 2014; Accepted: 26 February 2014

DOI of original article: $10.14218 /$ JCTH.2013.00028

Correspondence to: Mahmoud M. Bahgat, Research Group of Biomarkers for Infection and Immunity, Institute of Experimental Infection Research, TWINCORE Centre for Experimental and Clinical Infection Research, Feodor-Lynen-Straße 7-9 D - 30625 Hannover, Germany. Tel: +49 511-22 00 2-7172, Fax: +49 511-22 00 27-186, E-mails: mahmoud-bahgat.riad@twincore.de; mahmoud-bahgat.riad@ helmholtz-hzi.de both the immune system and liver pathology.

(c) 2014 The Second Affiliated Hospital of Chongqing Medical University. Published by XIA \& HE Publishing Ltd. All rights reserved.

\section{Introduction}

Helminth infections are one of the most common parasitic diseases found in tropical countries worldwide. ${ }^{1}$ The highest prevalence of such infections occur in underdeveloped regions with poor hygiene and inadequate water supply and sanitation. These populations often live on less than 2 US dollars per day. Helminthic infections are the most neglected of tropical diseases. ${ }^{1}$ Schistosomiasis, in particular, has been endemic in Egypt and other African countries located along the Nile River since antiquity. ${ }^{2}$ During the first half of the 20th century, up to $80 \%$ of the residents in impoverished Egyptian villages were infected with schistosome parasites, an incident that made a writer at that time declare, "No other people on earth suffer the consequences of bilharzial infection to the extent of the Egyptian farmers". ${ }^{2}$ Risk factors for active schistosomiasis transmission, including improper water and sanitation facilities and bodies of stagnant water contaminated with infected intermediate snail hosts, existed in poor Egyptian villages and dramatically contributed to the establishment of disease endemicity. ${ }^{2}$ Globally, chronic morbidities associated with repeated schistosomiasis infection include impaired child growth and development, chronic liver inflammation, anemia, and other nutritional deficiencies. It has been estimated that up to 56 million disability adjusted life years are lost annually, a value that exceeds the estimated global burden of malaria. ${ }^{3}$

Prior to the availability of oral praziquantel, the primary treatment for schistosomiasis in Egypt was tartar emetic (potassium antimony tartrate) administered parenterally. ${ }^{2}$ Hundreds of thousands of Egyptian farmers received the medication following World War I, which was, although highly toxic, often effective in curing schistosomiasis. The drug exerted its action via inhibition of DNA synthesis, ${ }^{4}$ and side effects included nausea, vomiting, coughing, acute circulatory failure, and electrocardiographic changes. ${ }^{5}$ Unfortunately, this drug was dispensed without due attention to sterilization of needles between patients and resulted in an unanticipated epidemic of hepatitis $\mathrm{C}$ virus (HCV) transmission. ${ }^{6-12}$ During this period, human blood and multiple syringe use were 
not known as possible routes for transmission of other infections. ${ }^{12}$ It has recently become evident that the parenteral administration of tartar emetic using non sterilized syringes resulted in widespread transmission of both HCV and HBV. ${ }^{13}$ Given the prevalence of schistosomiasis/HCV coinfection in Egyptians, higher susceptibility of this population was proposed. ${ }^{14,15}$ Two years ago, the prevalence of chronic HCV infections and seropositivity among Egyptians was reported to be one in 10 people, whereas the global rate was one in 50 people. ${ }^{16}$ In contrast, the seroprevalence of $\mathrm{HCV}$ and schistosomiasis in neighboring Sudan is much lower, and the reason for this difference is still unclear. ${ }^{17}$

Over the last decade, most papers published regarding human schistosomiasis began with a similar version of the following paragraph: "Schistosomiasis is the second most important parasitic infection after malaria and affects more than 200 million people in 74 countries. ${ }^{18}$ It is endemic, with high prevalence and morbidity rates in many countries, especially those in Africa, such as Egypt, ${ }^{19}$ Kenya $^{20}$ and Sudan ${ }^{12,22}$ and in South America, mainly Brazil. ${ }^{23}$ The largest epidemiological survey in Egypt mentioned the prevalence of Schistosoma haematobium in Upper Egypt (where it is endemic) to be around $7.8 \%$, while the prevalence of $\mathrm{S}$. mansoni in Lower Egypt (where it is endemic) was found to be around $36.4 \% .{ }^{19}$ When one carefully looks at the dates of the references for global prevalence of the human schistosomiasis, it becomes apparent that all results are outdated and represent more a history than a description of the current status.

The main reasons for this is that human schistosomiasis, among other helminth infections, became an extremely neglected tropical disease. ${ }^{1}$ During the 1990 's, the WHO, the Egyptian Government in collaboration with the USAID, ${ }^{24}$ and the EU allocated large funds to establish relationships between scientists from endemic countries for human schistosomiasis and collaborators form Europe and the USA. These funds were extremely useful in training young scientists and establishing an infrastructure in Egypt that enabled laboratories to seriously begin research on the control of human schistosomiasis. Unfortunately, the majority of the funds was spent on characterizing vaccine candidates, an aim which is to date still not achieved, and not on setting up concrete hygienic plans to eliminate human schistosomiasis from Egypt. Candidate schistosome antigens that were evaluated for their protective potential against schistosomiasis infection and their capacity to stimulate various host immune responses are listed in table 1 (reviewed in ${ }^{25}$ ). ${ }^{26-49}$ By the end of the 1990's, the funds expired, Western countries excluded human schistosomiasis from their research priorities, and Egypt declared schistosomiasis as a minor or no longer existing health problem. The dramatic absence of both international funding schemes and political willingness to help contributed to an extreme neglect of human schistosomiasis and other helminth, soil-, and mosquitoes-borne diseases in Egypt over the last twenty years.

The early schistosomiasis tartar emetic control campaign which resulted in $\mathrm{HCV}$ transmission ${ }^{8-13}$ led to the highest prevalence rates globally of HCV in Egypt, ${ }^{17}$ with many cases developing into chronic liver cirrhosis and hepatocellular carcinoma (HCC). Schistosoma and HCV appear to act synergistically in coinfected patients, causing more severe liver disease progression compared to either pathogen alone. ${ }^{50-60}$ Since praziquantel became the oral drug of choice to control human schistosomiasis, ${ }^{61}$ no injectable drugs are used for infection treatment. Nevertheless, HCV infection is frequently complicated by underlying $S$. mansoni coinfection, which has been associated with increased HCV morbidity and chronicity. ${ }^{62-64}$

Taken together, these findings make clear that although schistosomiasis is an extremely neglected tropical disease, it has contributed significantly to the spread of, the susceptibility to, and the pathological consequences of HCV infection.

The present review focuses on the immune evasion mechanisms of both schistosome parasites and HCV that might underlie the higher susceptibility of, and the severe disease outcome in, coinfected Egyptian patients. Also highlighted the poor anti-viral therapy outcome among coinfected subjects and proposed several future strategies that may help in resolving the puzzling relationship between human schistosomiasis and HCV infection.

\section{Helminth infections switch immune response to favor secondary viral infection}

Helminth infections exert profound suppressive effects on the host's immune response, which enable their worms to evade the defense mechanisms and survive in the blood, lymphatics, intestine, body cavities, or other tissues for years. ${ }^{65-67}$ Chronically infected filarial and schistosome patients present clinically with impaired immune responses, as demonstrated by reduced production of IL- 5 and IFN- $\gamma$, and occasionally IL$4 .{ }^{68-71}$ Although some elements of such immune suppression are reversible upon drug-mediated parasite clearance, ${ }^{70-72}$ drug treatments do not induce protective immunity against parasite challenge, and individuals can rapidly become reinfected upon re-exposure to the infective stages of these parasites. Therefore, innovative strategies to induce longterm protective immunity and to develop vaccines against helminth infections which can counteract infection-induced immune suppression are still lacking. Recently, serum CCL11 and CCL17 were identified as serological indicators of human multiple helminth infections. They were determined to be primarily driven by $S$. mansoni infection as these biomarkers significantly correlated with fecal bilharzia egg counts and bilharzial induced IL10. ${ }^{73}$ Besides modulation of the immune response, helminth infections cause chronic disease, including fatigue, iron deficiency anemia, growth stunting, malnutrition, and poor cognitive development. ${ }^{74}$ Both the immune suppressive effects and the severe pathological consequences resulting from chronic helminth infections represent risk factors that increase host predisposition to secondary viral infections.

Schistosomiasis infection induces $\mathrm{T}_{\mathrm{H}} 2$ responses that enhance both susceptibility to HCV infection and progression of liver pathology

One possible reason for both enhanced susceptibility to HCV infection and liver pathology is the shift in the immune response and corresponding cytokine release. While mounting a successful immune response against HCV infection would be characterized by a $T_{H} 1$ immunological profile that triggers a robust antiviral response and a reduction in host fibrosis, schistosomiasis triggers a $\mathrm{T}_{\mathrm{H}} 2$ cytokine response, which not only suppresses $\mathrm{T}_{\mathrm{H}} 1$ cytokine release (thereby hindering cellular and antiviral immunity) but also promotes subsequent $\mathrm{T}_{\mathrm{H}} 2$ responses and fibrogenesis. ${ }^{15,52,54,75-79}$ Such suppression of $\mathrm{T}_{\mathrm{H}} 1$ cytokines in case of $S$. mansoni/ $\mathrm{HCV}$ coinfection was reported to be mediated by antigens shed from dead parasite worms or eggs, and therefore did not 
Bahgat M.M.: Connection between human Schistosomiasis and HCV infection in Egypt

Table 1. Candidate schistosome antigens, their capacity to stimulate various host immune responses, and their protective potential against schistosomiasis infection

\begin{tabular}{|c|c|c|c|c|c|}
\hline Antigen & Form & $\begin{array}{l}\text { Induced immune } \\
\text { response }\end{array}$ & $\begin{array}{l}\text { Reduction of } \\
\text { egg count (\%) }\end{array}$ & $\begin{array}{l}\text { Reduction of } \\
\text { worm count (\%) }\end{array}$ & References \\
\hline Sm-p80 & DNA vaccine & $\begin{array}{l}\text { Th1, IgG, IgG2a and } \\
\text { IgG2b }\end{array}$ & 84 & 59 & 26 \\
\hline TSP-2 & Recombinant protein & IgG, IgG1 and IgG2a & $\sim 65$ & 57 & 27,28 \\
\hline Sm29 & Recombinant protein & $\begin{array}{l}\text { Th1, IgG, IgG1 and } \\
\text { IgG2a }\end{array}$ & 60 & 51 & 29,30 \\
\hline Sm200 (ECL) & DNA vaccine & IgG, IgG1 > IgG2a & ND & 38.1 & 13 \\
\hline $\mathrm{Sm} 25$ & Peptide vaccine & IgG & Significant & Significant & 32,33 \\
\hline Glutathione peroxidase & $\begin{array}{l}\text { DNA prime vaccinia } \\
\text { virus boost }\end{array}$ & ND & ND & 85 & 34 \\
\hline $\mathrm{Sm} 21.7$ & Recombinant protein & ND & ND & $41-70$ & 35 \\
\hline $\begin{array}{l}\text { Cu/Zn superoxide } \\
\text { dismutase }\end{array}$ & DNA vaccine & ND & ND & $44-60$ & 34 \\
\hline Filamin & DNA vaccine & $\begin{array}{l}\text { Th } 1 / 2, \operatorname{IgG}, \operatorname{IgG} 1 \text {, } \\
2 \mathrm{a} \text { and } 2 \mathrm{~b}\end{array}$ & ND & $44-57$ & 36 \\
\hline Sm fimbrin + Sm 21.7 & $\begin{array}{l}\text { Multivalent DNA } \\
\text { vaccine }\end{array}$ & IgG & $\begin{array}{l}41.5 \text { (Liver) } 55.6 \\
\text { (Intestine) }\end{array}$ & 56 & 37 \\
\hline Sm-p80 & DNA vaccine & Th1/Th17, IgG & ND & 47 & 38 \\
\hline Sm 23 & DNA vaccine & IgG & ND & 44 & 39,40 \\
\hline Sm 21.7 & DNA vaccine & IgG & $\begin{array}{l}62 \text { (liver) } 67 \\
\text { (intestine) }\end{array}$ & 41.53 & 41 \\
\hline Fimbrin & Recombinant protein & ND & ND & $39.4-41.6$ & 42 \\
\hline Sm 22.6 & Recombinant protein & $\begin{array}{l}\text { Th1/Th2, IgG, IgG1 } \\
\text { IgG2a }\end{array}$ & ND & 34.5 & 43 \\
\hline TSP-1 & Recombinant protein & IgG, IgG1 and IgG2a & $\begin{array}{l}52 \text { (liver) } 69 \\
\text { (feces) }\end{array}$ & 34 & 26,27 \\
\hline Stomatin like protein-2 & Recombinant protein & $\begin{array}{l}\text { Th1 IgG, IgG1 } \\
>\text { IgG2a }\end{array}$ & $\begin{array}{l}\text { No significant } \\
\text { difference }\end{array}$ & $30-32$ & 44 \\
\hline Sm 20.8 & DNA vaccine & ND & ND & $28.5-30.8$ & 45 \\
\hline Sm28GST & $\begin{array}{l}\text { DNA vaccine +plasmid } \\
\text { containing IL-18 }\end{array}$ & Th1, IgG & $\begin{array}{l}29.6 \% \text { (liver) } \\
27.5 \% \text { (intestine) }\end{array}$ & 22.6 & 46 \\
\hline Dif 5 & DNA vaccine & ND & ND & 22 & 47 \\
\hline SmIg & Recombinant protein & Th1/Th2, IgG & ND & No significant difference & 48 \\
\hline $\mathrm{Sm} 21.6$ & Recombinant protein & $\begin{array}{l}\text { Th1/Th2b IgG, } \\
\text { IgG1 > IgG2 }\end{array}$ & ND & No significant difference & 49 \\
\hline
\end{tabular}

require an active parasitic infection. ${ }^{34}$ The shift in immune response from $T_{H} 1$ to $T_{H} 2$ can be confirmed by high plasma levels of the profibrotic cytokines IL-4 and IL-13 and antiinflammatory cytokine IL-10. ${ }^{75-77,80-84}$

Consistent with this, it was reported that impaired interferon gamma (INF- $\gamma$ ) and tumor necrosis factor alpha (TNF- $\alpha$ ) production as well as impaired maturation of dendritic cells in a HCV patient who underwent liver transplantation resulted in an inadequate immune response to viral progression and caused relapsing $\mathrm{HCV}$ infection. ${ }^{85}$ In addition, induction of T- cells from infected humans with human T cell lymphotropic virus type 1 by three recombinant schistosome antigens, namely Sm29, ShTSP2 (tetraspanin), and PIII, caused downregulation of IFN- $\gamma$ production, which in turn enhanced virus propagation. ${ }^{86}$ Similarly, T-cell responses in blood from positive Egyptian patients for both anti-HCV and anti-Schistosoma antibodies showed a significant decrease in core-specific T-cell IFN- $\gamma$, IL-4, and IL-10 responses compared to T-cells in blood from Egyptian patients positive only for anti-HCV antibodies. ${ }^{56,76}$ The authors concluded that the presence of S. mansoni eggs in the liver inhibited local intrahepatic T-cell responses against $\mathrm{HCV}$ infection and consequently promoted persistent viral infection and accelerated the clinical course of HCV in HCV/S. mansoni coinfected humans. This could at that time provide a possible explanation for why coinfected patients have a higher incidence of cirrhosis and HCC than those matched for age, disease duration, and viral genotype with chronic HCV mono-infection. ${ }^{53}$

\section{Immune evasion mechanisms by both HCV and $S$. mansoni proteases enhance relapsing $\mathrm{HCV}$ infection and severe liver pathology}

Although escape from adaptive immunity is a key to long term persistence of HCV infection, evasion of innate antiviral 
Bahgat M.M.: Connection between human Schistosomiasis and HCV infection in Egypt

responses is crucial in establishing a persistent infection in the first place. ${ }^{87}$ As a main player in innate immunity against viruses, the IFN system is key in curtailing pathogens by putting infected and neighboring cells into an antiviral state. ${ }^{88} \mathrm{HCV}$ has been known for long time to be highly sensitive to treatment with type I IFNs, ${ }^{89,90}$ and to date, IFN$\alpha$ is the major component of HCV therapy. Since HCV is sensitive to IFN and can still manage to establish persistent infection, this suggests that the virus may have evolved mechanisms to circumvent the innate antiviral defense system. In fact, the viral serine protease domain, nonstructural protein (NS) 3/4A, was found to suppress activation of IFN regulatory factor 3 (IRF-3), a central antiviral transcription factor promoting the production of IFN- $\beta$ and a plethora of IFN-stimulated genes (ISGs), most prominently ISG56, ${ }^{91}$ in response to viral infection or treatment with doublestranded ribonucleic acid. ${ }^{87,92}$

Further identification of cellular targets of the HCV protease indicated that it interferes with both Toll-like receptor 3 (TLR3)-mediated signaling through cleavage of the essential adaptor TRIF (Toll/interleukin receptor domain containing adapter-inducing interferon $\beta)^{93,94}$, mitochondrial antiviral signaling protein ${ }^{95}$ and TLR-independent activation of IRF-3 by the cytosolic pathways of retinoic-acid inducible gene I (RIG-I) and MDA5 (melanoma differentiation associated protein 5 ) by inactivating the signaling adaptor CARDIF (also known as interferon-beta promoter stimulator 1 [IPS-1], mitochondrial anti-viral signaling protein [MAVS] and/or virus-induced signaling adaptor [VISA]). ${ }^{96}$ This indicated that both pathways may play a role in controlling HCV infection, most likely, in different sets of cells because TLR3 was shown to be essential for IFN production in plasmacytoid dendritic cells, whereas RIG-I triggers IFN secretion upon viral infection in conventional dendritic cells and other tissues. ${ }^{97}$ More recently, the preferential abrogation of the RIG-I-mediated pathway following proteolytic cleavage of CARDIF by the HCV NS3/4A protease ectopically expressed in human primary hepatocytes was reported. The TLR3-mediated pathway was affected to a lesser extent and in a protease-independent manner. ${ }^{98}$ In support of the impairment of innate anti-HCV responses, IRF3-dependent genes, type IFN- $\beta$, type III IL28A/ IL29 and chemokine CCL5 were significantly downregulated in association with a global decrease of CARDIF adaptor in liver biopsies and corresponding purified hepatocytes of chronic HCV patients. ${ }^{99}$ Altogether, these data suggest that HCV- NS3/ $4 \mathrm{~A}$ protease is an attractive anti-HCV drug target, and therefore, I and others molecularly characterized this protease and reported on selective serine protease inhibitors as potential anti-HCV therapeutics. ${ }^{90,100-103}$

A variety of proteases of various classes and clades were also reported to be differentially expressed in various developmental stages of the schistosome parasites. ${ }^{104-110}$ These were also demonstrated to be implicated in the evasion of the host immune mechanisms for the sake of establishing chronic bilharzial infection. Cercarial and schistosomular proteases were reported for their capacity to cleave both complement molecules ${ }^{11-115}$ and immunoglobulin $E^{116,117}$ and in this way prevented host mediated parasite killing by such molecules. Furthermore, helminth cysteine proteases were recently reported to inhibit TRIF-dependent activation of macrophages via degradation of TLR3, which represents an additional immune evasion mechanism by parasite worms. ${ }^{118}$

In murine systems, inhibition of schistosome proteases using either specific inhibitors, ${ }^{119}$ newly synthesized small organic molecules ${ }^{120,121}$ or by inducing specific immunity against DNA constructs encoding worm proteases ${ }^{122}$ resulted in partial protection against $S$. mansoni infection as demonstrated by either reduction in worm burden or egg counts.

\section{Response of $\mathrm{HCV} /$ schistosoma coinfected patients to IFN- $\alpha$ therapy}

Treatment of $\mathrm{HCV}$ with pegylated interferon and ribavirin represents the cornerstone and the standard of care for the management of the prevailing HCV genotype $4 \mathrm{a}$ (HCV-4a) in Egypt. ${ }^{123} \mathrm{HCV}-4 \mathrm{a}$ has been reported to be one of the most difficult genotypes to treat. ${ }^{123}$ One possible reason for this is the great diversity of virus quasi species present in each patient, which provides a reservoir of mutations that enable virus-escape from anti-viral therapy. ${ }^{124,125} \mathrm{~A}$ very recent study conducted on Egyptian patients clearly demonstrated a significant association between positive serology for schistosomal infection and failure to HCV treatment despite antischistosomal therapy with praziquantel. ${ }^{126}$ This further supports that bilharzial infection complicates HCV disease progression and treatment.

\section{Conclusions}

The lack of recent data regarding the actual prevalence of both human schistosomiasis and schistosomiasis/HCV coinfection clearly highlights the urgent need for active surveillance studies for both pathogens in Egypt. I believe that eliminating human schistosomiasis will significantly contribute to the reduction of both HCV prevalence and liver pathology among Egyptians and, as proposed by others, advocate plans for the elimination of human schistosome parasites from Egypt. ${ }^{127,128}$ The present review highlights the significant impact of the neglected tropical disease human schistosomiasis on both susceptibility of Egyptian patients to $\mathrm{HCV}$ coinfection, severity of the resulting liver pathology, and poor response to antiviral therapy. In addition to the exerted immune evasion mechanisms by the HCV-NS3/4A protease, I discuss for the first time the possible impact of immune evasion mechanisms exerted by proteases of larval, worm, and egg stages of the parasite Schistosoma on human susceptibility to HCV infection. In addition, schistosome immune evasion mechanisms are among the suppressive tactics of the parasite that prevents clearance of HCV viremia and leads to both relapsing HCV infection and severe liver pathology.

In fact, developing in vitro and in vivo models would enable the study of the impact of HCV-4a alone or in combination with live schistosome stages (schistosomula, worms and eggs) on liver pathogenesis and immune modulation. The in vitro system requires generation of a replicon system $^{129}$ from the most prevailing genotype (HCV-4a) in Egypt and establishment of its replication on hepatoplastoma or immune cells in presence of bilharzial antigens. ${ }^{60}$ The ideal in vivo system would be a humanized small animal model that can acquire both HCV and S. mansoni infections in order to study the impact of coinfection on both the immune system and liver pathology in real-time. ${ }^{130,131}$

Last but not least, both international collaborative and funding initiatives are needed to help resolve the puzzling relationship between human schistosomiasis and $\mathrm{HCV}$ infections. 


\section{Conflict of interest}

None

\section{Author contributions}

Writing the review (MMB).

\section{References}

[1] Hotez PJ, Brindley PJ, Bethony JM, King CH, Pearce EJ, Jacobson J. Helminth infections: the great neglected tropical diseases. J Clin Invest 2008;118: 1311-1321. doi: 10.1172/JCI34261.

[2] Farley J. Bilharzia: A History of Imperial Tropical Medicine. Cambridge University Press 1991;359.

[3] King $\mathrm{CH}$. Parasites and poverty: the case of schistosomiasis. Acta Trop 2010;113:95-104. doi: 10.1016/j.actatropica.2009.11.012

[4] Khafagy EZ, El-Harwary MF. Mechanism of action of bilharcid and tartaremetic. Zentralbl Bakteriol Naturwiss11978;133:320-340.

[5] Sundar S, Chakravarty J. Antimony Toxicity. Int J Environ Res Public Health 2010;7:4267-4277. doi: 10.3390/ijerph7124267.

[6] el-Sadawy M, Ragab H, el-Toukhy H, el-Mor Ael-L, Mangoud AM, Eissa MH, et al. Hepatitis C virus infection at Sharkia Governorate, Egypt: seroprevalence and associated risk factors. J Egypt Soc Parasitol 2004;34:367384.

[7] Medhat A, Shehata M, Magder LS, Mikhail N, Abdel-Baki L, Nafeh M, et al. Hepatitis $C$ in a community in Upper Egypt: risk factors for infection. Am J Trop Med Hyg 2002;66:633-638.

[8] Mohamed MK, Bakr I, El-Hoseiny M, Arafa N, Hassan A, Ismail S, et al. HCVrelated morbidity in a rural community of Egypt. J Med Virol 2006;78:11851189. doi: 10.1002/jmv.20679.

[9] Rao MR, Naficy AB, Darwish MA, Darwish NM, Schisterman E, Clemens JD, et al. Further evidence for association of hepatitis $C$ infection with parenteral schistosomiasis treatment in Egypt. BMC Infect Dis 2002;2:29. doi: 10.1186/1471-2334-2-29.

[10] Roulot D, Bourcier V, Grando V, Deny $P$, Baazia $Y$, Fontaine $H$,et al. Epidemiological characteristics and response to peginterferon plus ribavirin treatment of hepatitis C virus genotype 4 infection. J Viral Hepat 2007;14: 460-467. doi: 10.1111/j.1365-2893.2006.00823.x.

[11] Tanaka Y, Agha S, Saudy N, Kurbanov F, Orito $E$, Kato $T$, et al. Exponential spread of hepatitis C virus genotype 4a in Egypt. J Mol Evol 2004;58:191195. doi: 10.1007/s00239-003-2541-3.

[12] Williams R. Global challenges in liver disease. Hepatology 2006;44:521526. doi: 10.1002/hep.21347.

[13] El-Sabah AA, El-Metwally MT, Abozinadah NY. Hepatitis C and B virus in schistosomiasis patients on oral or parenteral treatment. J Egypt Soc Parasitol 2011:41:307-314.

[14] Blanton RE, Salam EA, Ehsan A, King CH, Goddard KA. Schistosomal hepatic fibrosis and the interferon gamma receptor: a linkage analysis using single-nucleotide polymorphic markers. Eur J Hum Genet 2005;13: 660-668.

[15] Elsammak MY, Al-Sharkaweey RM, Ragab MS, Amin GM, Kandil MH. In Egyptians, a mutation in the lymphotoxin- alpha gene may increase susceptibility to hepatitis $C$ virus but not that to schistosomal infection. Ann Trop Med Parasitol 2008;102:709-716. doi: 10.1179/ $136485908 \times 337599$.

[16] Yahia M. A uniquely Egyptian epidemic. Nature 2011;474:512-513. doi: $10.1038 / 474512 a$.

[17] Mudawi HM, Smith HM, Fletcher IA, Fedail SS. Prevalence and common genotypes of HCV infection in Sudanese patients with hepatosplenic schistosomiasis. J Med Virol 2007;79:1322-1324. doi: 10.1002/ jmv. 20865.

[18] WHO Expert Committee. Prevention and Control of Schistosomiasis and Soil-Transmitted Helminthiasis. World Health Organ Tech Rep Ser 2002; 912:1-57.

[19] El-Khoby T, Galal N, Fenwick A, Barakat R, El-Hawey A, Nooman Z, et al. The epidemiology of schistosomiasis in Egypt: summary findings in nine governorates. Am J Trop Med Hyg 2000;62:88-99.

[20] Blanton RE, Salam EA, Kariuki HC, Magak P, Silva LK, Muchiri EM, et al. Population-based differences in Schistosomiasis mansoni and hepatitis C induced disease. J Infect Dis 2002;1859:1644-1649. doi: 10.1086/ 340574.

[21] Homeida M, Ahmed S, Dafalla A, Suliman S, Eltom I, Nash T, et al. Morbidity associated with Schistosoma mansoni infection as determined by ultrasound: a study in Geriza, Sudan. Am J Trop Med Hyg 1988;39:196-201.
[22] Richter J, Monteiro E, Braz RM, Abdalla M, Abdel-Rahim IM, Fano U, et al. Sonografi corganometry in Brazilian and Sudanese patients with hepatosplenic schistosomiasis mansoni and its relation to the risk of bleeding from oesophageal varices. Acta Trop 1992;51:281-290. doi: 10.1016/0001706X(92)90046-Z

[23] Palmeira DC, Carvalho AG, Rodrigues K, Couto JL. Prevalence of Schistosoma mansoni infection in two municipalities of the State of Alagoas, Brazil. Rev Soc Bras Med Trop 2010;43:313-317. doi: 10.1590/ S0037-86822010000300020.

[24] El Khoby T, Galal N, Fenwick A. The USAID/Government of Egypt's Schistosomiasis Research Project (SRP). Parasitol Today 1998;14:92-96. doi: 10.1016/S0169-4758(97)01206-4

[25] Pinheiro CS, Martins VP, Assis NR, Figueiredo BC, Morais SB, Azevedo V et al. Computational vaccinology: an important strategy to discover new potential S. mansoni vaccine candidates. Journal of Biomedicine and Biotechnology. 2011;2011:503068. doi: 10.1155/2011/503068.

[26] Ahmad G, Torben W, Zhang W, Wyatt M, Siddiqui AA. Sm-p80-based DNA vaccine formulation induces potent protective immunity against Schistosoma mansoni. Parasite Immunol 2009;31:156-161. doi 10.1111/j.1365-3024.2008.01091.x.

[27] Tran MH, Pearson MS, Bethony JM, Smyth DJ, Jones MK, Duke M, et al. Tetraspanins on the surface of Schistosoma mansoni are protective antigens against schistosomiasis. Nat Med 2006;12:835-840. doi: 10.1038/nm1430.

[28] Hemler ME. Specific tetraspanin functions. J Cell Biol 2001;155:1103-1107. doi: $10.1083 / j \mathrm{jcb} .200108061$

[29] Cardoso FC, Macedo GC, Gava E, Kitten GT, Mati VL, de Melo AL, et al. Schistosoma mansoni tegument protein $\mathrm{Sm} 29$ is able to induce a Th1-type of immune response and protection against parasite infection. PLoS Neg Trop Dis 2008;2:e308. doi: 10.1371/journal.pntd.0000308.

[30] Liu F, Lu J, Hu W, Wang SY, Cui SJ, Chi M, et al. New perspectives on hostparasite interplay by comparative transcriptomic and proteomic analyses of Schistosoma japonicum. PLoS Pathog 2006: 2:268-281.

[31] Nascimento EJ, Amorim RV, Cavalcanti A, Alves VF, Nakazawa M, Pereira VR, et al. Assessment of a DNA vaccine encoding an anchored-glycosylphosphatidylinositol tegumental antigen complexed to protamine sulphate on immunoprotection against murine schistosomiasis. Mem Inst Oswaldo Cruz 2007;102:21-27. doi: 10.1590/S0074-02762007000100003.

[32] Pearce EJ, Magee AI, Smithers SR, Simpson AJ. Sm25, a major schistosome tegumental glycoprotein, is dependent on palmitic acid for membrane attachment. EMBO J 1991;10:2741-2746.

[33] Petzke MM, Suri PK, Bungiro R, Goldberg M, Taylor SF, Ranji S, et al. Schistosoma mansoni gene GP22 encodes the tegumental antigen Sm25: (1) Antibodies to a predicted B-cell epitope of Sm25 cross-react with other candidate vaccine worm antigens; (2) characterization of a recombinant product containing tandem-repeats of this peptide as a vaccine. Parasite Immunol 2000;22:381-395. doi: 10.1046/j.1365-3024.2000.00316.x.

[34] Shalaby KA, Yin L, Thakur A, Christen L, Niles EG, LoVerde PT. Protection against Schistosoma mansoni utilizing DNA vaccination with genes encoding $\mathrm{Cu} / \mathrm{Zn}$ cytosolic superoxide dismutase, signal peptide-containing superoxide dismutase and glutathione peroxidase enzymes. Vaccine 2003;22:130-136. doi: 10.1016/S0264-410X(03)00535-8.

[35] Ahmed HM, Mahmoud RH, Sherif SA, Fahim FA, Saber MA. Protection against Schistosoma mansoni infection with recombinant schistosomula 21.7 kDa protein. Arab J Biotech 2001;24:229-249.

[36] Cook RM, Carvalho-Queiroz C, Wilding G, LoVerde PT. Nucleic acid vaccination with Schistosoma mansoni antioxidant enzyme cytosolic superoxide dismutase and the structural protein filamin confers protection against the adult worm stage. Infect Immun $2004 ; 72: 6112-6124$. doi 10.1128/IAI.72.10.6112-6124.2004.

[37] Romeih MH, Hassan HM, Shousha TS, Saber MA. Immunization against Egyptian Schistosoma mansoni infection by multivalent DNA vaccine. Acta Biochim Biophys Sin (Shanghai) 2008;40:327-338. doi: 10.1111/j.17457270.2008.00404.x.

[38] Zhang W, Ahmad G, Torben W, Siddiqui AA. Smp80-based DNA vaccine made in a human use approved vector VR1020 protects against challenge infection with Schistosoma mansoni in mouse. Parasite Immunol 2010;32: 252-258. doi: 10.1111/j.1365-3024.2009.01181.x.

[39] Da 'dara AA, Skelly PJ, Wang MM, Harn DA. Immunization with plasmid DNA encoding the integral membrane protein, $\mathrm{Sm} 23$, elicits a protective immune response against schistosome infection in mice. Vaccine 2001;20:359369. doi: 10.1016/S0264-410X(01)00374-7.

[40] Da 'dara AA, Skelly PJ, Fatakdawala M, Visovatti S, Eriksson E, Harn DA. Comparative efficacy of the Schistosoma mansoni nucleic acid vaccine, Sm23, following microseeding or gene gun delivery. Parasite Immunol 2002;24:179-187. doi: 10.1046/j.1365-3024.2002.00453.x.

[41] Ahmed HM, Romeih MH, Abou Shousha TS, Dabaa EEM, Saber MA. DNA Immunization with the gene encoding $\mathrm{Sm} 21.7$ protein protects mice against Schistosoma mansoni infections. Am J Sci 2006;2:59-69.

[42] Saber MA and Hamid AH. Molecular cloning, purification and characterization of Schistosoma mansoni fimbrin. Arab J Biotech 1998;1:1-16. 
[43] Pacifico LG, Fonseca CT, Chiari L, Oliveira SC. Immunization with Schistosoma mansoni $22.6 \mathrm{kDa}$ antigen induces partial protection against experimental infection in a recombinant protein form but not as DNA vaccine. Immunobiology 2006;211:97-104. doi: 10.1016/ j.imbio.2005.06.004.

[44] Farias LP, Cardoso FC, Miyasato PA, Montoya BO, Tararam CA, Roffato HK, et al. Schistosoma mansoni stomatin like protein-2 is located in the tegument and induces partial protection against challenge infection. PLoS Negl Trop Dis 2010;4:e597. doi: 10.1371/journal.pntd.0000597.

[45] Mohamed MM, Shalaby KA, LoVerde PT, Karim AM. Characterization of Sm20.8, a member of a family of schistosome tegumental antigens. Mol Biochem Parasitol 1998;96:15-25. doi: 10.1016/S0166-6851(98)000887.

[46] Dupre L, Kremer L, Wolowczuk I, Riveau G, Capron A, Locht C. Immunostimulatory effect of IL-18-encoding plasmid in DNA vaccination against murine Schistosoma mansoni infection. Vaccine 2001;19:13731380. doi: 10.1016/S0264-410X(00)00363-7.

[47] Farias LP, Tararam CA, Miyasato PA, Nishiyama MY Jr, Oliveira KC, Kawano T, et al. Screening the Schistosoma mansoni transcriptome for genes differentially expressed in the schistosomulum stage in search for vaccine candidates. Parasitol Res 2011;108:123-135. doi: 10.1007/s00436-0102045-1.

[48] Pinho M, Cardoso FC, Lopes DO, Pinheiro CS, Caliari MV, Oliveira FM, et al. Immunization with SmIg, a novel tegument protein from Schistosoma mansoni, fails to induce protection in mice but reduces liver pathology. Parasitology 2010;137:1079-1088. doi: 10.1017/S0031182009991387.

[49] Lopes DO, Paiva LF, Martins MA, Cardoso FC, Rajão MA, Pinho JM, et al. Sm21.6 a novel EF-hand family protein member located on the surface of Schistosoma mansoni adult worm that failed to induce protection against challenge infection but reduced liver pathology. Vaccine 2009;27:41274135. doi: 10.1016/j.vaccine.2009.04.068.

[50] Darwish MA, Raouf A, Rushdy P, Constantine NT, Rao MR, Edelman R. Risk factors associated with a high sero-prevalence of hepatits $C$ virus infection in Egyptian blood donors. Am J Trop Med Hyg 1993;49:440-447.

[51] Gad A, Tanaka E, Orii K, Rokuhara A, Nooman Z, Serwah AH, et al. Relationship between hepatitis $C$ virus infection and schistosomal liver disease: not simply an additive effect. Journal of Gastroenterology 2001; 36:753-758. doi: 10.1007/s005350170017.

[52] Kamal SM, Bianchi L, Al Tawil A, Koziel M, El Sayed Khalifa K, Peter T, et al. Specific cellular immune response and cytokine patterns in patients coinfected with hepatitis C virus and Schistosoma mansoni. J J Infect Dis 2001;184:972-982. doi: 10.1086/323352.

[53] Kamal S, Madwar M, Bianchi L, Tawil AE, Fawzy R, Peters T, et al. Clinical, virological and histopathological features: long-term follow-up in patients with chronic hepatitis C co-infected with S. mansoni. Liver 2000;20:281289. doi: $10.1034 / j .1600-0676.2000 .020004281 . x$.

[54] Kamal SM, Graham CS, He Q, Bianchi L, Tawil AA, Rasenack JW, et al. Kinetics of intrahepatic hepatitis $C$ virus (HCV)-specific CD4+ T cell responses in $\mathrm{HCV}$ and Schistosoma mansoni coinfection: relation to progression of liver fibrosis. J Infect Dis 2004;189:1140-1150. doi: $10.1086 / 382278$.

[55] Edwards MJ, Buchatska O, Ashton M, Montoya M, Bickle QD, Borrow P. Reciprocal immunomodulation in a schistosome and hepatotropic virus coinfection model. J Immunol 2005;175:6275-6285.

[56] Farid A, Al-Sherbiny M, Osman A, Mohamed N, Saad A, Shata MT, et al. Schistosoma infection inhibits cellular immune responses to core HCV peptides. Parasite Immunol 2005;27:189-196. doi: 10.1111/j.13653024.2005.00762.x.

[57] El-Awady MK, Youssef SS, Omran MH, Tabll AA, El Garf WT, Salem AM. Soluble egg antigen of Schistosoma haematobium induces HCV replication in PBMC from patients with chronic HCV infection. BMC Infect Dis 2006;6: 91. doi: 10.1186/1471-2334-6-91.

[58] Kamal SM, Turner B, He Q, Rasenack J, Bianchi L, Al Tawil A, et al. Progression of fibrosis in hepatitis $C$ with and without schistosomiasis: correlation with serum markers of fibrosis. Hepatology 2006;43:771-779. doi: 10.1002/hep.21117.

[59] Strickland GT. Liver disease in Egypt: hepatitis C superseded schistosomiasis as a result of iatrogenic and biological factors. Hepatology $2006 ; 43$ : 915-922. doi: 10.1002/hep.21173.

[60] Bahgat MM, El-Far MA, Mesalam AA, Ismaeil AA, Ibrahim AA, Gewaid HE, et al. Schistosoma mansoni soluble egg antigens enhance HCV replication in mammalian cells. J Infect Dev Ctries 2010;4:226-234.

[61] Webbe G, el Hak S. Progress in the control of schistosomiasis in Egypt 1985-1988. Trans R Soc Trop Med Hyg 1990;84:394-400. doi: 10.1016/ 0035-9203(90)90334-B.

[62] Kamal SM, Graham CS, He Q, Bianchi L, Tawil AA, Rasenack JW, et al. Kinetics of intrahepatic hepatitis C virus (HCV)-specific CD4+ T cell responses in $\mathrm{HCV}$ and Schistosoma mansoni coinfection: relation to progression of liver fibrosis. J Infect Dis 2004;189:1140-1150. doi: $10.1086 / 382278$.
[63] Farid A, Al-Sherbiny M, Osman A, Mohamed N, Saad A, Shata MT, et al. Schistosoma infection inhibits cellular immune responses to core $\mathrm{HCV}$ peptides. Parasite Immunol 2005;27:189-196. doi: 10.1111/j.13653024.2005.00762.x

[64] Kamal SM, Bianchi L, Al Tawil A, Koziel M, El Sayed Khalifa K, Peter T, et al. Specific cellular immune response and cytokine patterns in patients coinfected with hepatitis $C$ virus and Schistosoma mansoni. J Infect Dis 2001;184:972-982. doi: 10.1086/323352.

[65] Maizels RM, Balic A, Gomez-Escobar N, Nair M, Taylor MD, Allen JE. Helminth parasites - Masters of regulation. Immunol Rev 2004;201:89116. doi: 10.1111/j.0105-2896.2004.00191.x.

[66] Bethony JM, Brooker S, Albonico M, Geiger SM, Loukas A, Diemert D, et al Soil-transmitted helminth infections: ascariasis, trichuriasis, and hookworm. Lancet 2006;367:1521-1532. doi: 10.1016/S01406736(06)68653-4.

[67] Hoerauf A, Satoguina J, Saeftel M, Specht S. Immunomodulation by filarial nematodes. Parasite Immunol 2005;27:417-429. doi: 10.1111/j.13653024.2005.00792.x

[68] Babu S, Blauvelt CP, Kumaraswami V, Nutman TB. Regulatory networks induced by live parasites impair both Th1 and Th2 pathways in patentlymphatic filariasis: implications for parasite persistence. J Immunol 2006; 176:3248-3256.

[69] Grogan JL, Kremsner PG, Deelder AM, Yazdanbakhsh M. Antigen-specific proliferation and interferon-gamma and interleukin- 5 production are downregulated during Schistosoma haematobium infection. J Infect Dis 1998; 177:1433-1437. doi: 10.1086/517832.

[70] Sartono E, Kruize YC, Kurniawan A, Maizels RM, Yazdanbakhsh M. Depression of antigen-specific interleukin-5 and interferon-gamma responses in human lymphatic filariasis as a function of clinical status and age. J Infect Dis 1997;175:1276-1280. doi: 10.1086/593701.

[71] Elliott DE, Summers RW, Weinstock JV. Helminths as governors of immunemediated inflammation. Int J Parasitol 2007;37:457-464.

[72] Grogan JL, Kremsner PG, Deelder AM, Yazdanbakhsh M. Elevated proliferation and interleukin-4 release from CD4+ cells after chemotherapy in human Schistosoma haematobium infection. Eur J Immunol 1996;26: $1365-1370$.

[73] Geiger SM, Jardim-Botelho A, Williams W, Alexander N, Diemert DJ, Bethony JM. Serum CCL11 (eotaxin-1) and CCL17 (TARC) are serological indicators of multiple helminth infections and are driven by Schistosoma mansoni infection in humans. Trop Med Int Health 2013;18:750-760. doi: 10.1111/tmi.12095.

[74] Maizels RM and Yazdanbakhsh M. Immune regulation by helminth parasites: cellular and molecular mechanisms. Nat Rev Immunol 2003;3: 733-744. doi: 10.1038/nri1183.

[75] El-Kady IM, El-Masry SA, Badra G, Halafawy KA. Different cytokine patterns in patients coinfected with hepatitis $C$ virus and Schistosoma mansoni. Egypt J Immunol 2004;11:23-29.

[76] El-Kady IM, Lotfy M, Badra G, El-Masry S, Waked I. Interleukin (IL)-4, IL10, IL-18 and IFN-gamma cytokines pattern in patients with combined hepatitis $\mathrm{C}$ virus and Schistosoma mansoni infections. Scand J Immunol 2005;61:87-91.

[77] Emam EA, Emam M, Shehata AE, Emara M. Impact of Schistosoma mansoni co-infection on serum profile of interferon-gamma, interleukin-4 and interleukin-10 in patients with chronic hepatitis C virus infection. Egypt J Immunol 2006;13:33-40.

[78] Actor JK, Shirai M, Kullberg MC, Buller RM, Sher A, Berzofsky JA. Helminthic infection results in decreased virus-specific CD8+ cytotoxic T cell and TH1 cytokine response as well as delayed virus clearance. Proc Natl Acad Sci U S A 1993;90:948-952. doi: 10.1073/pnas.90.3.948.

[79] El-Zayadi AR. Hepatitis C comorbidities affecting the course and response to therapy. World J Gastroenterol 2009;15:4993-4999.

[80] Abbas OM, Abdel-Rahman MH, Omar NA, Badran HM, Amir EM. Interleukin10 promoter polymorphisms in hepatitis $C$ patients with and without Schistosoma mansoni co-infection. Liver Int 2009;29:1422-1430. doi: 10.1111/j.1478-3231.2009.02068.x.

[81] Elsammak MY, Al-Sharkaweey RM, Ragab MS, Amin GA, Kandil MH. IL-4 and reactive oxygen species are elevated in Egyptian patients affected with schistosomal liver disease. Parasite Immunol 2008;30:603-609.

[82] Hassoba H, Leheta O, Sayed A, Fahmy H, Fathy A, Abbas F, et al. IL-10 and IL-12p40 in Egyptian patients with HCV-related chronic liver disease. Egypt Journal of Immunol 2003;10:1-8.

[83] Burke ML, Jones MK, Gobert GN, Li YS, Ellis MK, McManus DP. Immunopathogenesis of human schistosomiasis. Parasite Immunol 2009 , 31:163-176. doi: 10.1111/j.1365-3024.2009.01098.x.

[84] Wynn TA. IL-13 effector functions. Annu Rev Immunol 2003;21:425-456. doi: 10.1146/annurev.immunol.21.120601.141142.

[85] Ocaña L, Cos J, Quer J, Bilbao I, Palou E, Parra R, et al. Analysis of INFgamma, TNF- alpha and dendritic cells to predict hepatitis C virus recurrence in liver transplant patients. Transplant Proc 2005;37:39513956. doi: 10.1016/j.transproceed.2005.09.183. 
[86] Lima LM, Santos SB, Oliveira RR, Cardoso LS, Oliveira SC, Góes AM, et al. Schistosoma antigens downmodulate the in vitro inflammatory response in individuals infected with human T cell lymphotropic virus type 1. Neuroimmunomodulation 2013;20:233-238. doi: 10.1159/000348700.

[87] Thimme R, Lohmann V, Weber F. A target on the move: innate and adaptive immune escape strategies of hepatitis C virus. Antiviral Res 2006;69:129141. doi: 10.1016/j.antiviral.2005.12.001.

[88] Van Boxel-Dezaire AH, Rani M, Stark G. Complex modulation of cell typespecific signaling in response to type I interferons. Immunity $2006 ; 25$ : 361-372. doi: 10.1016/j.immuni.2006.08.014.

[89] Hoofnagle JH, Mullen KD, Jones DB, Rustgi V, Di Bisceglie A, Peters M, et al. Treatment of chronic non- $A$, non-B hepatitis with recombinant human alpha interferon: a preliminary report. N Engl J Med 1986;315:1575-1578.

[90] Opar A. Excitement grows for potential revolution in hepatitis C virus treatment. Nat Rev Drug Discov 2010;9:501-503. doi: 10.1038/nrd3214.

[91] Grandvaux N, Servant M, Tenoever B, Sen GC, Balachandran S, Barber GN, et al. Transcriptional profiling of interferon regulatory factor 3 target genes: direct involvement in the regulation of interferon-stimulated genes. J Virol 2002;76:5532-5539. doi: 10.1128/JVI.76.11.5532-5539.2002.

[92] Foy E, Li K, Wang C, Sumpter R Jr, Ikeda M, Lemon SM, et al. Regulation of interferon regulatory factor- 3 by the hepatitis $C$ virus serine protease. Science 2003;300:1145-1148. doi: 10.1126/science.1082604.

[93] Li K, Foy E, Ferreon J, Nakamura M, Ferreon AC, Ikeda M, et al. Immune evasion by hepatitis $C$ virus NS3/4A protease-mediated cleavage of the Tolllike receptor 3 adaptor protein TRIF. Proc Natl Acad Sci U S A 2005;102: 2992-2997. doi: 10.1073/pnas.0408824102.

[94] Loo YM, Owen DM, Li K, Erickson AK, Johnson CL, Fish PM, et al. Viral and therapeutic control of IFN-beta promoter stimulator 1 during hepatitis $C$ virus infection. Proc Natl Acad Sci U S A 2006;103:6001-6006. doi: 10.1073/pnas.0601523103.

[95] Li XD, Sun L, Seth RB, Pineda G, Chen ZJ. Hepatitis C virus protease NS3/4A cleaves mitochondrial antiviral signaling protein off the mitochondria to evade innate immunity. Proc Natl Acad Sci U S A 2005;102:17717-17722. doi: $10.1073 /$ pnas.0508531102.

[96] Meylan E, Curran J, Hofmann K, Moradpour D, Binder M, Bartenschlager R, et al. Cardif is an adaptor protein in the RIG-I antiviral pathway and is targeted by hepatitis C virus. Nature 2005;437:1167-1172. doi: $10.1038 /$ nature04193.

[97] Kato H, Sato S, Yoneyama M, Yamamoto M, Uematsu S, Matsui K, et al. Cell type-specific involvement of RIG-I in antiviral response. Immunity 2005; 23:19-28. doi: 10.1016/j.immuni.2005.04.010.

[98] Jouan L, Melancon P, Rodrigue-Gervais IG, Raymond VA, Selliah S, Boucher $\mathrm{G}$, et al. Distinct antiviral signaling pathways in primary human hepatocytes and their differential disruption by HCV NS3 protease. J Hepatol 2010;52: 167-175. doi: 10.1016/j.jhep.2009.11.011.

[99] Jouan L, Chatel-Chaix L, Melançon P, Rodrigue-Gervais IG, Raymond VA, Selliah $\mathrm{S}$, et al. Targeted impairment of innate antiviral responses in the liver of chronic hepatitis C patients. J Hepatol 2012;56:70-77. doi: 10.1016/j.jhep.2011.07.017.

[100] Bahgat MM, Ibrahim AA, Abd-Elshafy DN, Mesalam AA, Gewaid HE, Ismaeil $\mathrm{AA}$, et al. Characterization of NS3 protease from an Egyptian HCV genotype 4a isolate. Arch Virol 2009;154:1649-1657. doi: 10.1007/s00705-0090500-Z.

[101] Jiang Y, Andrews SW, Condroski KR, Buckman B, Serebryany V, Wenglowsky S, et al. Discovery of Danoprevir (ITMN-191/R7227), a Highly Selective and Potent Inhibitor of Hepatitis C Virus (HCV) NS3/4A Protease. J Med Chem 2014;57:1753-1769. doi: 10.1021/jm400164c

[102] Meeprasert A, Rungrotmongkol T, Li MS, Hannongbua S. In Silico Screening for Potent Inhibitors against the NS3/4A Protease of Hepatitis C Virus. Curr Pharm Des, 2013 Sep 2. [Epub ahead of print].

[103] Djerada Z, Feliu C, Tournois C, Vautier D, Binet L, Robinet A, et al. Validation of a fast method for quantitative analysis of elvitegravir, raltegravir, maraviroc, etravirine, tenofovir, boceprevir and 10 other antiretroviral agents in human plasma samples with a new UPLC-MS/MS technology. J Pharm Biomed Anal 2013;86:100-111. doi: 10.1016/j.jpba.2013.08. 002.

[104] McKerrow JH, Jones $P$, Sage H, Pino-Heiss S. Proteinases from invasive larvae of the trematode parasite Schistosoma mansoni degrade connective-tissue and basement-membrane macromolecules. Biochem J 1985; 231:47-51.

[105] Bahgat M, Francklow K, Doenhoff MJ, Li YL, Ramzy RM, Kirsten C, et al. Infection induces antibodies against the cercarial secretions, but not against the cercarial elastases of Schistosoma mansoni, Schistosoma haematobium, Schistosoma japonicum and Trichobilharzia ocellata. Parasite Immunol 2001;23:557-565. doi: 10.1046/j.1365-3024.2001. 00417.x.

[106] Ruppel A, Chlichlia K, Bahgat M. Invasion by schistosome cercariae: neglected aspects in Schistosoma japonicum. Trends Parasitol 2004;20: 397-400. doi: 10.1016/j.pt.2004.06.006.
[107] Delcroix M, Sajid M, Caffrey CR, Lim KC, Dvorák J, Hsieh I, et al. A multienzyme network functions in intestinal protein digestion by a platyhelminth parasite. J Biol Chem 2006;281:39316-39329. doi: 10.1074/jbc.M607128200.

[108] Dvorák J, Mashiyama ST, Braschi S, Sajid M, Knudsen GM, Hansell E, et al. Differential use of protease families for invasion by schistosome cercariae. Biochimie 2008;90:345-358. doi: 10.1016/j.biochi.2007.08 013.

[109] Dvorák J, Mashiyama ST, Sajid M, Braschi S, Delcroix M, Schneider EL, et al. SmCL3, a gastrodermal cysteine protease of the human blood fluke Schistosoma mansoni. PLoS Negl Trop Dis 2009;3:e449. doi: 10.1371/ journal.pntd.0000449.

[110] Ashton PD, Harrop R, Shah B, Wilson RA. The schistosome egg: development and secretions. Parasitology 2001;122:329-338. doi: 10.1017/ S0031182001007351.

[111] Marikovsky M, Arnon R, Fishelson Z. Proteases secreted by transforming schistosomula of Schistosoma mansoni promote resistance to killing by complement. J Immunol 1988;141:273-278.

[112] Marikovsky M, Parizade M, Arnon R, Fishelson Z. Complement regulation on the surface of cultured schistosomula and adult worms of Schistosoma mansoni. Eur J Immunol 1990;20:221-227.

[113] Fishelson Z. Novel mechanisms of immune evasion by Schistosoma mansoni. Mem Inst Oswaldo Cruz 1995;90:289-292. doi: 10.1590/ S0074-02761995000200029.

[114] McKerrow JH, Newport G, Fishelson Z. Recent insights into the structure and function of a larval proteinase involved in host infection by a multicellular parasite. Proc Soc Exp Biol Med 1991;197:119-124. doi: 10.3181/00379727-197-43233.

[115] Ghendler Y, Parizade M, Arnon R, McKerrow JH, Fishelson Z. Schistosoma mansoni: evidence for a 28-kDa membrane-anchored protease on schistosomula. Experimental Parasitology 1996;83:73-82. doi: 10.1006/ expr.1996.0051.

[116] Pleass RJ, Kusel JR, Woof JM. Cleavage of human IgE mediated by Schistosoma mansoni. Int Arch Allergy Immunol 2000;121:194-204. doi: 10.1159/000024317

[117] Aslam A, Quinn P, McIntosh RS, Shi J, Ghumra A, McKerrow JH, et al Proteases from Schistosoma mansoni cercariae cleave IgE at solvent exposed interdomain regions. Mol Immunol 2008;45:567-574. doi: 10.1016/j.molimm.2007.05.021.

[118] Donnelly S, O'Neill SM, Stack CM, Robinson MW, Turnbull L, Whitchurch C, et al. Helminth cysteine proteases inhibit TRIF-dependent activation of macrophages via degradation of TLR3. J Biol Chem 2010;285:3383-3392. doi: $10.1074 /$ jbc.M109.060368.

[119] Lim KC, Sun E, Bahgat M, Bucks D, Guy R, Hinz RS, et al. Blockage of skin invasion by schistosome cercariae by serine protease inhibitors. Am J Trop Med Hyg 1999;60:487-492.

[120] Bahgat MM, Maghraby AS, Heiba ME, Ruppel A, Fathalla OA. Synthesis of new 4-oxo-2-thioxo-1,2,3,4-tetrahydropyrimidine derivatives with an incorporated thiazolidinone moiety and testing their possible serine protease and cercarial elastase inhibitory effects with a possible prospective to block penetration of Schistosoma mansoni cercariae into the mice skin. Arch Pharm Res 2005;28:1002-1012. doi: 10.1007/ BF02977392.

[121] Bahgat M, Aboul-Enein MN, El Azzouny AA, Maghraby A, Ruppel A, Soliman WM. A cyclohexanecarboxamide derivative with inhibitory effects on Schistosoma mansoni cercarial serine protease and penetration of mice skin by the parasite. Acta Pol Pharm 2009;66:333-340.

[122] Chlichlia K, Bahgat M, Ruppel A, Schirrmacher V. DNA vaccination with asparaginyl endopeptidase (Sm32) from the parasite Schistosoma mansoni: anti-fecundity effect induced in mice. Vaccine $2001 ; 20: 439-447$. doi: 10.1016/S0264-410X(01)00345-0.

[123] Esmat G, El Raziky M, El Kassas M, Hassany M, Gamil ME. The future for the treatment of genotype 4 chronic hepatitis C. Liver Int 2012;32 146-150. doi: 10.1111/j.1478-3231.2011.02704.x.

[124] Fan X, Mao Q, Zhou D, Lu Y, Xing J, Xu Y, et al. High diversity of hepatitis C viral quasispecies is associated with early virological response in patients undergoing antiviral therapy. Hepatology 2009;50:1765-1772. doi: 10.1002/hep.23290.

[125] Al-Qahtani AA, Kessie G, Dela Cruz D, Al-Faleh FZ, Al-Ahdal MN. Quasispecies of genotype 4 of hepatitis $C$ virus genomes in Saudi patients managed with interferon alfa and ribavirin therapy. Ann Saudi Med 2010; 30:109-114. doi: 10.4103/0256-4947.60515.

[126] Abdel-Rahman M, El-Sayed M, El Raziky M, Elsharkawy A, El-Akel W, Ghoneim $\mathrm{H}$, et al. Coinfection with hepatitis $C$ virus and schistosomiasis: fibrosis and treatment response. World J Gastroenterol 2013;19:26912696.

[127] Sanghvi MM, Hotez PJ, Fenwick A. Neglected tropical diseases as a cause of chronic liver disease: the case of Schistosomiasis and Hepatitis C Coinfections in Egypt. Liver Int 2013;33:165-168. doi: 10.1111/liv.12052. 
Bahgat M.M.: Connection between human Schistosomiasis and HCV infection in Egypt

[128] Rollinson D, Knopp S, Levitz S, Stothard JR, Tchuem Tchuenté LA, Garba A et al. Time to set the agenda for schistosomiasis elimination. Acta Trop 2013;128:423-440. doi: 10.1016/j.actatropica.2012.04.013.

[129] Pietschmann T, Bartenschlager $R$. The hepatitis $C$ virus replicon system and its application to molecular studies. Curr Opin Drug Discov Devel 2001;4: 657-664. Review.
[130] MacArthur KL, Wu CH, Wu GY. Animal models for the study of hepatitis C virus infection and replication. World J Gastroenterol 2012;18:29092913.

[131] Dorner M, Horwitz JA, Donovan BM, Labitt RN, Budell WC, Friling T, et al. Completion of the entire hepatitis $C$ virus life cycle in genetically humanized mice. Nature 2013;501:237-241. doi: 10.1038/nature12427. 